\title{
ПРОБЛЕМЫ И СОВЕРШЕНСТВОВАНИЕ ПРАКТИКИ НАЗНАЧЕНИЯ НЕКОТОРЫХ ВИДОВ НАКАЗАНИЙ ЗА КОРРУПЦИОННЫЕ ПРЕСТУПЛЕНИЯ В СОЦИАЛЬНОЙ СФЕРЕ
}

Аннотация: Предметом статьи являются проблемы правового и организационного характера, связанные с совершенствованием практики назначения некоторых видов наказаний за коррупционные преступления в соииальной сфере. Автор подробно рассматривает такие аспекты темы как совериенствование практики назначения наказания за коррупционные преступления в Российской Федерации. Детально анализируется практика применения данных наказаний за последние годы. Отмечается, что практика назначения наказаний за коррупционные преступления - в том числе и за коррупциионые преступления в социиальной сфере - постоянно изменялась, что неразрывно связано с постоянным реформированием уголовного права в части наказаний по коррупционным составам УК РФ. Кроме того, в статье проводится судебной практике имеющей место в рассматриваемой сфере. Методологическую основу статьи составили современные достижения теории познания. В процессе исследования применялись общефилософский, теоретический, общефилософские методы (диалектика, системный метод, анализ, синтез, аналогия, дедукиия, наблюдение, моделирование), традиционно правовые методы (формально-логический), а также методы, используемые в конкретно-социологических исследованиях (статистические, экспертные оценки и др.). Основным вкладом, который сделан автором в настоящей статье это то, что основными направлениями совериенствования практики назначения наказаний за коррупционные преступления в социильной сфере должны стать: сокрашение использования в качестве наказания лишения свободы условно. В этой связи делается вывод, что это не означает систематического применения в качестве наказаний по данной категории дел реальных сроков; стоит рассмотреть пути совершенствования в использования такого вида дополнительного наказания по данной категории дел как конфискация; наконеи, к систематическому использованию в отношении коррупционеров социального сектора такого наказания как лишение права занимать должности, связанные с выполнением властных, организационно-распорядительных функиий должен быть использован более гибкий и дифференцированный подход.

Ключевые слова: Коррупция, преступление, взятка, дача, наказание, соичильная, практика, суд, назначение, ответственность.

Abstract: This article focuses on the issues of legal and organizational character associated with the improvement of prescribing practices for certain punishments for crimes of corruption in the social sphere. The author carefully considers the aspects of the topic such as improving the practice of sentencing for crimes of corruption in the Russian Federation. Analysis is conducted on the practice of application of these penalties in recent years. It is noted that the practice of sentencing for corruption (including for crimes of corruption in the social sphere) constantly changed, which is linked to the constant reform of the criminal law in terms of punishment for corruption according to the criminal code. This work also analyzes the judicial practice in this sphere. The main contribution made by the author in this article is that the key directions of improving the practice of sentencing for crimes of corruption in the social sphere should be reduction in the use of the penalty of imprisonment. The author concludes that the systemic application of prison sentences for this category of crime should be replaced with a systemic application of punishment in form of confiscation, revocation of the right to hold any public office, and apply a more flexible and differentiated approach. Keywords: Responsibility, designation, trial, practice, social, punishment, property, bribe, crime, corruption .

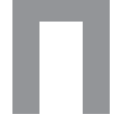
рактика назначения наказаний за коррупционные преступления является довольно сложным явлением претерпевшим за сравнительно небольшой срок времени ряд значительных изменений. Основной сложностью данной практики является множественность видов наказаний применяемых за коррупционные преступления, а также посто- янные видоизменения уголовного законодательства в части наказаний за коррупционные преступления, которые усложняют и постоянно видоизменяют саму практику их назначения.

Законодатель предоставил органам судебной власти целый набор видов наказаний, которые они могут применять за коррупционные преступления как 
в качестве основных, так и дополнительных. Относя коррупционные преступления к тяжким и особо тяжким, законодатель справедливо - и в соответствии с международными обязательствами Российской Федерации -предусмотрел лишение свободы как один из видов наказания за данные преступления. В тоже время, являясь корыстными по своей природе, коррупционные преступления вполне справедливо потребовали и применения наказаний в виде денежного взыскания, а именно применения в качестве наказания за данные преступления штрафов - которые по мысли законодателя являются наиболее эффективным средством в борьбе с коррупцией - а также возможность применения такой меры уголовно-правового воздействия в отношении осужденного по отдельным коррупционным составам как конфискация. Принимая во внимание, что большая часть коррупционных преступлений относится к категории преступлений против государственной службы такой вид наказания как лишение права занимать должности, связанные с выполнением властных, организационно-распорядительных функций, объясняется здесь несоответствием личности осужденного коррупционера с этическими принципами государственной службы и, как следствие, невозможностью такими лицами выполнять должностные функции. Аналогичным образом можно объяснить, на наш взгляд, и применение в качестве наказания за коррупционные преступления лишение специального, воинского или почетного звания, классного чина и государственных наград. Наконец, введение законодателем в Уголовный кодекс новых видов наказания [1] - отдельные из которых также применяются и к лицам признанным виновными за коррупционные преступления - расширило список применяемых за коррупционные преступления наказаний и, как следствие, также усложнило практику применения наказаний за данные преступления.

Стоит отметить, что практика назначения наказаний за коррупционные преступления - в том числе и за коррупционные преступления в социальной сфере - постоянно изменялась, что неразрывно связано с постоянным реформированием уголовного права в части наказаний по коррупционным составам УК РФ. В советский период развития уголовного права, практика назначения наказаний за коррупционные преступления шла по пути их ужесточения, что отразилось и в ужесточении уголовных наказаний за них [2] и, соответственно, на практике назначения наказаний за них. Так в Уголовном кодексе 1960 г. получение взятки должностным лицом занимающим ответственное положение, либо ранее судимым за взяточничество, а также за взяточничество в особо крупном размере наказывались в том числе смертной казнью. С гуманизацией современного уголовного права (Уголовный кодекс 1996 г.) законодатель установил возможность применения за наименее опасные формы коррупционных преступлений более мягкой формы уголовного наказания - штрафа. Позднее, законодатель [3] разрешил использовать штраф в качестве основного наказания за все - в том числе и наиболее тяжкие - категории коррупционных составов УК РФ. Следствием таких законодательных изменений стало изменение практики назначения наказаний по данной категории дел: штраф стал сегодня основным видом наказания за коррупционные преступления.

Необходимо отметить, что относительно используемых видов наказаний за коррупционные преступления в социальной сфере практика их назначения не отличается от практики назначения наказаний за коррупционные преступления в целом. Иначе говоря, к коррупционерам социальной сферы - как и к осужденным за коррупционные преступления в целом - применяется весь набор предусмотренных за коррупционные преступления видов наказаний. Так, например, в деле о выдаче врачом листков временной нетрудоспособности, при отсутствии в действительности у пациента заболевания, к врачу были применены такие виды наказания, предусмотренные п. 2 ст. 290 УК РФ как 3 года лишения свободы условно, с испытательным сроком в 3 года, а также лишение права занимать должности в медицинских учреждениях сроком на три года [4]. В большинстве своем в рамках коррупционных дел в социальной сфере - равно как и в рамках коррупционных процессов в целом - в качестве основного наказания чаще всего применяются штрафы [5]. Исключением остаются лишь исправительные работы, которые неохотно используются органами правосудия как в качестве наказания за коррупционные преступления в социальной сфере, так и за коррупционные преступления в целом.

Если практика назначения наказания за коррупционные преступления не раз стала объектом исследования Верховного суда Российской Федерации, то практика назначения наказания за коррупционные преступления в социальной сфере не получила такой привилегии, что связано с высокой латентностью коррупционных преступлений в социальной сфере и как следствие незначительным количеством таких дел, а также тем что в качестве основного направления уголовной антикоррупционной политики стала борьба с коррупцией вне социальной сферы (в частности в правоохранительных органах). Действительно, ни в Обзоре судебной практики Верховного Суда 


\section{Право и политика $10(202) \cdot 2016$}

Российской Федерации за второй квартал 2012 года [6], ни в Постановлении № 24 Пленума Верховного суда Российской Федерации от 9 июля 2013 г. « О судебной практике по делам взяточничестве и об иных коррупционных преступлениях» [7] мы не обнаружим разъяснений касательно назначения наказаний за коррупционные преступления именно в социальной сфере. Более того, статистические данные составляемые органами государственной власти в отношении коррупционных преступлений в соответствии с Указаниями Генеральной прокуратуры № 52-11/2 от 15 февраля 2012 г. «О введении в действие перечней статей Уголовного кодекса Российской Федерации, используемых при формировании статистической отчетности» [8] не содержат сведений о коррупционной преступности и осужденных по данной категории дел в зависимости от сферы жизнедеятельности.

Если в соответствии с общефедеральными статистическими данными подготовленными Генеральной прокуратурой России [9] количество зарегистрированных коррупционных преступлений постоянно растет, что свидетельствует о росте и интенсивности борьбы с данным явлением, то количество осужденных лиц - в сравнении с другими категориями дел - остается довольно невысоким: к уголовной ответственности привлекается около 13 процентов от общего количества возбужденных дел [10]. Более того, общее число направленных в суд уголовных дел коррупционной направленности и количество обвиняемых по направленным в суд делам, а, как следствие, и применяемых уголовных санкций за данные преступления также сокращается. Причем соотношение уголовных дел возбужденных в отношении должностных лиц социального сектора с уголовными делами возбужденными в отношении должностных лиц других сфер жизнедеятельности практически не изменяется: основная категория осужденных коррупционеров приходиться на последних. Такую диспропорцию можно объяснить как антикоррупционной политикой, направленной на борьбу с коррупцией - в первую очередь в правоохранительных органах, а также тем, что - по статистике-коррупционеров социальной сферы довольно непросто привлечь к ответственности в связи тем, что нередко лицо, совершившее преступление, не является должностным лицом, и, как следствие, не может являться субъектом преступления.

Так если по статистике за 2012 г. было в общем привлечено к уголовной ответственности за коррупционные преступления 7433 лица, то к уголовной ответственности должностных лиц органов социальной защиты и здравоохранения за данные преступления было привлечено всего-навсего 659 лиц, тогда как должностных лиц научных и образовательных учреждений и того меньше - 396. В свою очередь, основанная масса осужденных должностных лиц пришлась на представителей правоохранительных органов 2120 должностных лиц [11]. В рамках статистических данных составленных Генпрокуратурой Российской Федерации также представлено процентное содержание представителей социальной сферы среди общего количества привлеченных к уголовной ответственности, которые подтверждают их незначительность в сравнении с привлеченными к уголовной ответственности по коррупционным составам УК РФ представителей правоохранительных органов: из общего числа приговоренных к уголовному наказанию за коррупционные преступления должностных лиц, на представителей сферы здравоохранения и социального обеспечения приходиться не более 18 процентов осужденных, тогда как должностные лица сферы образования и науки осужденные по коррупционным составам УК РФ представляют всего-навсего 15 процентов от общего числа осужденных коррупционеров.

Статистические данные [12] свидетельствуют что из предусмотренных за коррупционные преступления наказаний и мер уголовно-правового воздействия (лишение свободы; штраф; исправительные работы; принудительные работы и лишение права занимать должности или заниматься определенной деятельностью; лишение специального, воинского или почетного звания, классного чина и государственных наград; конфискация) на практике в качестве наказания за коррупционные преступления в социальной сфере применяются в основном лишение свободы и штрафы. Причем это подтверждается как в отношении применения этих видов наказаний в виде основных и дополнительных наказаний, т.е. они являются основными видами наказания по данной категории дел вне зависимости от того применяются они в качестве основных или дополнительных.

Действительно, по свидетельству Генпрокуратуры Российской Федерации в общей статистике по назначению наказаний по данной категории дел основными видами наказания, назначаемого осужденным за совершение коррупционных преступлений, попрежнему являются - лишение свободы и, в первую очередь, штраф [13]. Исключением не стали и наказания, назначаемые осужденным за совершение коррупционных преступлений в социальной сфере [14], где статистика идентична.

По уже высказанным нами причинам, практика назначения наказаний за коррупционные преступле- 
ния в целом пошла по пути все большего применения в качестве наказания именно штрафов. Так, по все той же статистике Генеральной прокуратуры к штрафу в виде основного вида наказания за коррупционные преступления приговорен 51 \% осужденных по данной категории дел. Статистические данные за 2014 г. подготовленные Судебным департаментом Верховного суда Российской Федерации [15] подтверждают данную тенденцию: из общего количества привлеченных к уголовной ответственности по составам коррупционной направленности (10748), штраф в качестве основного наказания был назначен в отношении 6370 лиц. Более того, в отношении 1369 лиц штраф был назначен и в качестве дополнительного наказания. То есть в той или иной мере штраф был применен в качестве основного или дополнительного наказания к более чем 72 процентам осужденным по коррупционным делам, что явно свидетельствует о том что на сегодняшний день он является основным видом уголовного наказания за коррупционные преступления.

Размеры штрафов налагаемых на лиц осужденных по коррупционным составам УК РФ довольно высоки, что привело к критике со стороны научного сообщества, а также недавним внесениям изменений в уголовное законодательство [16]. Стоит тем не менее отметить, что на практике средний размер штрафов не является настолько запредельным как он нем свидетельствует научная общественность [17], а в сравнении с зарубежными примерами - даже при учете разницы уровня доходов - российские штрафы являются относительно невысокими. За неимением статистики по размеру штрафов, вменяемых физическим лицам за коррупционные преступления в рамках уголовных процессов, но располагая в тоже время данными о том, что средний размер взяток на 2013 г. колеблется в размере от 500 рублей до 10000 рублей, штраф назначенный, например, в качестве основного наказания по составу закрепленному ч. 3 ст. 291 - наибольшее количество коррупционных дел рассматривается именно в рамках данного состава УК РФ - не может превышать шестидесятикратного размера - т.е. 600000 руб.

В отсутствии уголовной ответственности юридических лиц за коррупционные преступления стоит сказать несколько слов об их административной ответственности по данной категории дел, так как она непосредственно связана с уголовно-правовой ответственностью физических лиц по данной категории дел, а такая мера наказания как штраф, как и в уголовном процессе, является основным видом наказания и в административных антикоррупционных делах. Действительно возбуждение прокурором административных производств в отношении юридических лиц по коррупционным делам (ст. 19.28 КоАП) осуществляется как следствие уголовного процесса возбужденного в отношении физического лица и неразрывно связано с ним, а штрафы здесь также являются, чуть ли не единственной мерой воздействия на коррупционера. Более того, за неимением уголовно-правовой ответственности юридических лиц в российском правопорядке здесь сложно предположить применение каких-либо других санкций за коррупционные преступления совершаемые юридическими лицами. Исключением остается конфискация, которая в соответствии со ст. 19. 28 КоАП также же может быть применена в отношении юридических лиц в качестве административной ответственности за незаконное вознаграждение. Как следствие, единственным видом ответственности юридических лиц по данной категории правонарушений остается административная ответственность юридических лиц (штраф и конфискация), что конечно же не соответствует тяжести данных правонарушений, т.е. в данном случае, на наш взгляд, вид ответственности и количество видов наказаний юридических лиц не соответствуют (непропорциональны) тяжести правонарушения, а также целям современной уголовной политики по борьбе с коррупцией.

По статистике количество административных дел в рамках которых в отношении юридических лиц была применена ответственность по ст. 19.28 КоАП невелико. В соответствии с данными Судебного департамента при Верховном суде Российской Федерации за 2013 г. [18] количество юридических лиц подвергнутых наказанию по данной статье КоАП не превышает 170: 156 лиц подвергнуто наказанию на основании ч. 1 ст. 19.28 КоАП и, всего-навсего, 8 лиц на основании ч. 2 ст. 19.28 КоАП. За неимением других видов наказаний (за исключением конфискации) в отношении всех из указанных юридических лиц в качестве основного наказания был назначен штраф. Лишь в 17 случаях конфискация применялась в отношении данных лиц в качестве дополнительного наказания.

Если общее количество дел об административных правонарушениях возбужденных в отношении юридических лиц по ст. 19.28 КоАП невелико, то дел возбужденных в отношении незаконного вознаграждения юридических лиц социального сектора практически не существует. Одним из редких примеров может служить решение суда по делу за совершение действий по выдаче юридическому лицу лицензии на право ведения образовательной деятельности в отсутствие необходимых документов [19]. Как следствие, развитие борьбы с коррупционными действиями юри- 


\section{Право и политика $10(202) \cdot 2016$}

дических лиц должно идти в направлении либо расширения их (например увеличения видов наказаний) административно-правовой ответственности, либо посредством введения уголовной ответственности юридических лиц. В отсутствии соответствующих законодательных реформ, единственным средством повышения эффективности административно-правового наказания за коррупционные правонарушения может стать только более эффективная работа прокуратуры как единственного субъекта располагающего полномочием на возбуждение административных производств по ст. 19.28 КоАП.

Лишение свободы в рамках уголовных процессов по коррупционным составам является вторым - после штрафа - наиболее распространённым видом наказания применяемого за совершение коррупционных преступлений. Действительно количество физических лиц осужденных по коррупционным составам за 2014 г. [20] к лишению свободы составило 4042 лица, что составляет 37,6 процента от общего количества осужденных по данной категории дел (10 784). Более того, из всего количества осужденных к лишению свободы менее половины из них было приговорено к реальным срокам заключения (1361), тогда как условное лишение свободы было вынесено в отношении большинства из них (2681). В итоге, из общего количества осужденных по данной категории дел (10748) к лишению свободы на определённый срок (1361) было приговорено менее 13 процентов $(12,66)$ лиц осужденных по данной категории дел.

Сроки лишения свободы применяемые в отношении коррупционеров невелики. Причем это характерно к в случае с реальным лишением свободы, так и в случаях с применением условного осуждения к лишению свободы. Действительно, по статистике [21], реальное лишение свободы на определенный срок по категории коррупционных преступлений не превышает трех лет. Из 1361 приговоренного по коррупционным составам в 2014 г. к реальному лишению свободы: 364 были приговорены к сроку менее 1-го года; 308 к сроку от 1-го до 2-х лет; 273 на срок от 2-х до 3-х лет. Иначе говоря, 945 из 1361 осужденного к реальному сроку лишения свободы (т.е. ок. 70 процентов от общего числа осужденных к лишению свободы по данной категории дел к реальному сроку лишения) были приговорены к незначительным срокам лишения свободы (до 3-х лет).

Аналогичным образом дело обстоит и в случае с условным осуждением к лишению свободы по коррупционным составам. Из 2681 осужденного к условному лишению свободы лишь 307 из них были осуждены на срок превышающий 3 года.
Стоит отметить что незначительность доли осужденных к реальным срокам лишения свободы по коррупционным составам - а также незначительность сроков лишения свободы назначаемых осужденным по данным составам - в сравнении с другими более мягкими видами наказаний применяемых к осужденным коррупционерам (штраф и условное осуждение к лишению свободы) свидетельствует о том, что на практике коррупционные правонарушения не рассматриваются как тяжкие и особо тяжкие преступления. Это противоречит на наш взгляд серьезности с которой коррупция рассматривается как населением, так и представителями государственной власти, а также с обозначенными направлениями в современной уголовной политике российского государства. Более того, согласимся с тем, что такой подход «...означает низкую эффективность уголовной ответственности за анализируемые деяния и не способствует достижению установленных ст. 43 УК РФ целей уголовного наказания» [22].

Если на первый взгляд применение такого - довольно распространённого в отношении должностных лиц правоохранительных органов привлеченных за совершение коррупционных преступлений - вида наказания как лишение права занимать определенные должности или заниматься определенной деятельностью, должно, в связи со своей непродуктивностью в отношении представителей социальной сферы (см. ниже $\S 2$ ), применяться к ним лишь в исключительных случаях, на практике применение данного наказания к осужденным за коррупционные преступления в социальной сфере является нередким явлением. Так, например, известны случаи применения данного наказания за выдачу сотрудником медицинского учреждения листа временной нетрудоспособности, по уходу за больным ребенком, при отсутствии в действительности у пациента какого-либо заболевания [23].

По статистическим данным подготовленным Генеральной прокуратурой России за 2012 г. [24] в качестве дополнительного наказания чаще всего назначалось лишение права занимать определенные должности или заниматься определенной деятельностью (19\% осужденных), а также штраф (9\% осужденных). Лишь в отдельных случаях - по свидетельствам Генеральной прокуратуры России - осужденные также лишались специального, воинского или почетного звания, классного чина и государственных наград. Иначе говоря, среди указанных видов дополнительных наказаний, лишение права занимать определенные должности или заниматься определенной деятельностью на практике являются наиболее часто применяемыми по данной категории дел. 
DOI: $10.7256 / 1811-9018.2016 .10 .17894$

При цитировании этой статьи сноска на doi обязательна

Закон и правопорядок

В тоже время, применение таких видов наказаний как лишение права занимать определенные должности или заниматься определенной деятельностью, а также лишение специального, воинского или почетного звания, классного чина и государственных наград довольно редко применяется в качестве основного наказания по коррупционным составам УК РФ. По статистическим данным за 2014 г. [25] из общего количества (10764) осужденных по коррупционным составам УК РФ лишь к 123 из них было применено наказание в виде лишения права занимать определенные должности или заниматься деятельностью в качестве основного вида наказания, т.е. данный вид наказания был применен лишь в отношении 1,14 процента осужденных по данной категории дел.

Статистика по применению данной санкции в качестве дополнительного наказания серьезно отличается от статистики его применения в качестве основного наказания. Действительно, применение данного наказания в качестве дополнительного вида наказания за коррупционные преступления является довольно распространенным. Популярность применения в качестве дополнительного наказания лишения права занимать определенные должности или заниматься определенной деятельностью в рамках уголовных дел по коррупционным составам УК РФ вызвана, на наш взгляд, разъяснениями Верховного суда РФ по применению данного наказания в рамках коррупционных процессов [26]. Действительно, из общего количества осужденных (10764) по коррупционным составам УК РФ лишение права занимать определенные должности или заниматься определенной деятельностью было применено в качестве дополнительного наказания в 1191 случае, т.е. данный вид наказания был применен в отношении 11 процентов осужденных по данной категории дел. Именно в такой форме данный вид наказания чаще всего применяется и к коррупционерам социальной сферы [27].

Непопулярен у представителей органов уголовного правосудия и такой вид наказания за коррупционные преступления как лишение специального, воинского или почетного звания, классного чина и государственных наград, который был применен к лишь 31 осужденному коррупционеру, т.е. лишь в отношении 0,28 процента от общего числа осужденных по данной категории дел (10764). В тоже время, стоит отметить, что - помимо того, что данный вид наказания не применяется в отношении осужденных по отдельным коррупционным составам (коммерческий подкуп) - ограниченное применение данного вида наказания является вполне естественным, так как не все должностные лица располагают специальными, воинскими или почетными званиями, классными чинами и государственными наградами [28]. Это тем более актуально для категории служащих социальной сферы, где - как и в большинстве секторов гражданской службы-применение званий и классных чинов ограничено по природе своей. Как следствие, неудивительно, что если применение данного вида наказания невелико даже и в общей доле наказаний, применяемых по коррупционным составам УК РФ, то применение данного вида наказания в отношении коррупционеров социального сектора нами и вовсе не было обнаружено при проведении анализа судебной практики по коррупционным составам УК РФ.

Стоит сказать несколько слов о применении за коррупционные преступления и такой меры уголовноправового воздействия как конфискация имущества (п. 1 ст. 104.1 УК РФ). Применение данной меры уголовно-правового воздействия в отношении осужденных за коррупционные преступления, являющиеся по природе своей корыстными, не является удивительным, так как - как и штраф - денежное взыскание в виде конфискации за коррупционные преступления является - как и в случае как и с любыми корыстными преступлениями - эффективным предупреждающим средством борьбы с ними [29].

Конфискация имущества была применена к 395 осужденному коррупционеру, т.е. лишь в отношении 3,66 процента от общего количества осужденных (10764) по данной категории дел в 2014 г. Такое незначительное использование данного вида уголовно-правового воздействия возможно объясняется отсутствием указания на возможность применения данных мер уголовно-правового воздействия в коррупционных составах Особенной части УК РФ: оно упоминается лишь в Общей части УК РФ. Более того, не все коррупционные преступления позволяют применение данного вида санкций: так, например, конфискация имущества невозможна в отношении осужденного по ст. 291 УК РФ (а), п. 1 ст. 104.1 УК РФ).

Ограниченное применение данного вида мер уголовно-правового воздействия за коррупционные преступления является неудовлетворительным на наш взгляд, так как данные санкции носят не меньший предупредительный потенциал в борьбе с коррупционными преступлениями, чем штрафы. Более того, о расширении практики применения данного вида санкций в отношении коррупционеров уже неоднократно упоминалось как учеными, так и представителями государственной власти [30].

Наконец, стоит отметить, что наименьшей популярностью у органов правосудия при выборе наказаний за коррупционные преступления пользуются 
DOI: $10.7256 / 1811-9018.2016 .10 .17894$

При цитировании этой статьи сноска на doi обязательна

\section{Право и политика $10(202) \cdot 2016$}

такие виды наказаний как принудительные, обязательные и исправительные работы. Обязательные и исправительные работы были применены к 29 и 13 осужденным по коррупционным составам УК РФ, соответственно, т.е. лишь в отношении 0,26 процента от общего количества осужденных (10764) по данной категории дел в 2014 г. в том что касается обязательных работ и в отношении 0,12 процента от общего количества осужденных (10764) по данной категории дел в 2014 г. в том что касается исправительных работ. Иначе говоря, применение данных видов наказания за коррупционные преступления является не только редким но даже и исключительным.

Стоит отметить, что также как и конфискация имущества, обязательные и исправительные работы не упоминаются в положениях Особенной части УК РФ, посвященных коррупционным составам - исключением остается коммерческий подкуп за совершение которого предусмотрены принудительные работы, что не способствует их популяризации среди представителей органов правосудия. Как следствие, такой низкий процент применения данного вида наказания за коррупционные преступления вполне логичен.

Практика применения наказаний за коррупционные преступления в России соответствует международным стандартам. Более того, виды наказаний предусмотренных по коррупционным составам вполне соответствуют зарубежным аналогам, где в качестве основных применяются такие меры наказания как штраф и лишение свободы.

Практика назначения наказаний в социальной сфере в целом идентична практике назначения наказаний за совершение коррупционных преступлений в целом. Здесь также в первую очередь применяется штраф, тогда как другие виды наказаний - в частности лишение права занимать определенные должности или заниматься определенной деятельностью - применяются, чаще всего, лишь в качестве дополнительного наказания. Применение таких видов наказания как лишение специального, воинского или почетного звания, классного чина и государственных наград, а также такой меры уголовно-правового воздействия как конфискация на практике практически не применяются.

\section{Библиография:}

1. Авдеев В.А. Принудительные работы как новый вид наказания в системе мер уголовно-правового характера // Известия Иркутской государственной экономической академии. 2012. № 6. С. 100.

2. Указ Президиума Верховного Совета СССР от 20 февраля 1962 г. «Об усилении уголовной ответственности за взяточничество»//С3 СССР. 1990. Т. 10. - с. 564.

3. Федеральный закон Российской Федерации от 4 мая 2011 г. № 97-Ф3 «О внесении изменений в Уголовный кодекс Российской Федерации и Кодекс Российской Федерации об административных правонарушениях в связи с совершенствованием государственного управления в области противодействия коррупции»//Российская газета от 6 мая 2011 г.

4. Архив суда Ленинского района г. Саратова. 2009 год.

5. Астафьева Т.А., Филоненко Т.В. Коррупция в сфере образования / Владивостокский центр исследования организованной преступности//www.crime.vl.ru/index.php?p=3636

6. Утвержден Президиумом Верховного Суда Российской Федерации 10 октября 2012 г.// Бююлетень Верховного суда. - № 1. - 2013.

7. Бюллетень Верховного суда. - № 9. - 2013.

8. Перечень преступлений коррупционной направленности № 23//Приложение к Указанию Генеральной прокуратуры Российской Федерации и № 52-11/2 и МВД Российской Федерации № 2 от 15 февраля 2012 г. «О введении в действие перечней статей Уголовного кодекса Российской Федерации, используемых при формировании статистической отчетности»

9. Статистические и аналитические материалы о состоянии работы по выявлению коррупционных преступлений, следствия и прокурорского надзора за уголовно-процессуальной деятельностью правоохранительных органов в сфере борьбы с коррупцией в 2012 г.// http://genproc.gov.ru/anticor/doks/document-81540/

10. Статистические и аналитические материалы о состоянии работы по выявлению коррупционных преступлений, следствия и прокурорского надзора за уголовно-процессуальной деятельностью правоохранительных органов в сфере борьбы с коррупцией в 2012 г.// http://genproc.gov.ru/anticor/doks/document-81540/

11. Статистические и аналитические материалы о состоянии работы по выявлению коррупционных преступлений, следствия и прокурорского надзора за уголовно-процессуальной деятельностью правоохранительных органов в сфере борьбы с коррупцией в 2012 г.// http://genproc.gov.ru/anticor/doks/document-81540/

12. Плохов С.В. Противодействие коррупции в социальной сфере (на примере здравоохранения и образования Волгоградской и Саратовской областей). Дисс... канд. юрид. наук. - Саратов. - 2013. с. 85, 86.

13. Плохов С.В. Противодействие коррупции в социальной сфере (на примере здравоохранения и образования Волгоградской и Саратовской областей). Дисс... канд. юрид. наук. - Саратов. - 2013. с. 85, 86.

14. Борисова Е.А. Коррупция в системе высшего образования: перспективы социального контроля, региональный аспект: дисс. ... канд. соц. наук. - Москва, 2013. - 220 с.

15. Раздел 6 формы № 10.4.1 «Отчет о результатах рассмотрения уголовных дел по отдельным статьям Уголовного кодекса Российской Федерации по вступившим в законную силу приговорам и другим судебным постановлениям, в том числе по преступлениям коррупционной направленности»// http://www.cdep.ru/index.php?id=150\&item=2881 
16. Федеральный закон Российской Федерации от 8 марта 2015 г. № 40-Ф3 «О внесении изменений в отдельные законодательные акты Российской Федерации»//Российская газета от 11 марта 2015 г.

17. Боровых Л. Проблемы практики применения уголовного законодательства РФ об ответственности за взяточничество, коммерческий подкуп и иные коррупционные преступления// Уголовное право. 2013. № 5. С. 39-40

18. Сводные статистические сведения о деятельности федеральных судов общей юрисдикции и мировых судей за 2013 г. («Отчет о работе судов общей юрисдикции по рассмотрению дел об административных правонарушениях № 1-АП»)// http://www.cdep.ru/index.php?id=79\&item=2361

19. Решение Ленинского районного суда г. Ростова-на-Дону//URL: http://www. rospravosudie.com/ court-leninskij-rajonnyjsud-g-rostova-na-donu-rostovskaya-oblast-s/act-103211142

20. Раздел 6 формы № 10.4.1 «Отчет о результатах рассмотрения уголовных дел по отдельным статьям Уголовного кодекса Российской Федерации по вступившим в законную силу приговорам и другим судебным постановлениям, в том числе по преступлениям коррупционной направленности»// http://www.cdep.ru/index.php?id=150\&item=2881

21. Раздел 6 формы № 10.4.1 «Отчет о результатах рассмотрения уголовных дел по отдельным статьям Уголовного кодекса Российской Федерации по вступившим в законную силу приговорам и другим судебным постановлениям, в том числе по преступлениям коррупционной направленности»// http://www.cdep.ru/index.php?id=150\&item=2881

22. Плохов С.В. Противодействие коррупции в социальной сфере (на примере здравоохранения и образования Волгоградской и Саратовской областей). Дисс... канд. юрид. наук. - Саратов. - 2013. с. 89

23. Архив суда Ленинского района г. Саратова. 2009 год.

24. Статистические и аналитические материалы о состоянии работы по выявлению коррупционных преступлений, следствия и прокурорского надзора за уголовно-процессуальной деятельностью правоохранительных органов в сфере борьбы с коррупцией в 2012 г.// http://genproc.gov.ru/anticor/doks/document-81540/

25. Раздел 6 формы № 10.4.1 «Отчет о результатах рассмотрения уголовных дел по отдельным статьям Уголовного кодекса Российской Федерации по вступившим в законную силу приговорам и другим судебным постановлениям, в том числе по преступлениям коррупционной направленности»// http://www.cdep.ru/index.php?id=150\&item=2881

26. Постановление Верховного Суда Российской Федерации от 9 июля 2013 г. № 24 «О судебной практике по делам о взяточничестве и другим коррупционным преступлениям» уточнил (п. 36), что «...судам следует обсуждать вопрос о необходимости назначения виновному в совершении коррупционного преступления лицу дополнительного наказания в виде лишения права занимать определенные должности или заниматься определенной деятельностью, имея в виду, что такой вид наказания может быть назначен независимо от того, предусмотрен ли он санкцией уголовного закона, по которому квалифицированы действия осужденного».

27. Архив суда Ленинского района г. Саратова. 2009 год.

28. Моисеенко В.П. Лишение специального, воинского или почетного звания, классного чина и государственных наград как вид наказания в российском уголовном праве: Уголовный и уголовно-исполнительный аспекты. Дисс...канд. юрид. наук. - 2000. - Ростов-на-Дону. - с. 165

29. Дурнев А.Е. Криминологические и уголовно-правовые меры борьбы с корыстными преступлениями против собственности. Дисс...канд. юрид. наук. М., 2006. 162 с.

30. Козлова Н. Бастрыкин просит вернуть радикальные меры против коррупции / Российская газета от 24 ноября 2014.

31. Букалерова Л.А., Фортуна К.А. К вопросу о наказаниях за коррупционные служебные подлоги // Административное и муниципальное право. - 2012. - 6. - С. $17-25$.

32. Куракин А.В., Костенников М.В. Административно-правовое противодействие коррупции в системе государственной службы и в деятельности сотрудников полиции Российской Федерации и зарубежных государств // Полицейская и следственная деятельность. - 2013. - 1. - С. 65 - 83. DOI: 10.7256/2409-7810.2013.1.735. URL: http://www.e-notabene.ru/pm/article_735.html

33. Костенников М.В., Куракин А.В. Административно-правовое противодействие коррупции в системе государственной службы и в деятельности сотрудников полиции Российской Федерации и зарубежных государств. // Полицейская деятельность. - 2011. - 1. - С. $10-16$.

34. Букалерова Л.А., Фортуна К.А. К вопросу о наказаниях за коррупционные служебные подлоги // Административное и муниципальное право. - 2012. - 6. - С. $17-25$.

35. М.В. Костенников, А.В. Куракин, И.Н. Кошелев Административно-правовое регулирование обеспечения собственной безопасности и противодействия коррупции в органах внутренних дел (ч. 2) // Административное и муниципальное право. - 2011. - 2. - С. $38-45$.

36. Куракин А.В., Костенников М.В. Административно-правовое противодействие коррупции в системе государственной службы и в деятельности сотрудников полиции Российской Федерации и зарубежных государств // Полицейская и следственная деятельность. - 2013. - 1. - С. 65 - 83. DOI: 10.7256/2409-7810.2013.1.735. URL: http://www.e-notabene. $\mathrm{ru} / \mathrm{pm} /$ article_735.html

37. Костенников М.В., Куракин А.В. Административно-правовое противодействие коррупции в системе государственной службы и в деятельности сотрудников полиции Российской Федерации и зарубежных государств. // Полицейская деятельность. $-2011 .-1 .-$ С. $10-16$.

\section{References (transliterated):}

1. Avdeev V.A. Prinuditel'nye raboty kak novyi vid nakazaniya v sisteme mer ugolovno-pravovogo kharaktera // Izvestiya Irkutskoi gosudarstvennoi ekonomicheskoi akademii. 2012. № 6. S. 100. 
DOI: $10.7256 / 1811-9018.2016 .10 .17894$

При цитировании этой статьи сноска на dоі обязательна

Право и политика $10(202) \cdot 2016$

2. Astaf'eva T.A., Filonenko T.V. Korruptsiya v sfere obrazovaniya / Vladivostokskii tsentr issledovaniya organizovannoi prestupnosti//www.crime.vl.ru/index.php? $=3636$

3. Plokhov S.V. Protivodeistvie korruptsii v sotsial'noi sfere (na primere zdravookhraneniya i obrazovaniya Volgogradskoi i Saratovskoi oblastei). Diss... kand. yurid. nauk. - Saratov. - 2013. s. 85, 86.

4. Plokhov S.V. Protivodeistvie korruptsii v sotsial'noi sfere (na primere zdravookhraneniya i obrazovaniya Volgogradskoi i Saratovskoi oblastei). Diss... kand. yurid. nauk. - Saratov. - 2013. s. 85, 86.

5. Borisova E.A. Korruptsiya v sisteme vysshego obrazovaniya: perspektivy sotsial'nogo kontrolya, regional'nyi aspekt: diss. ... kand. sots. nauk. - Moskva, 2013. - 220 s.

6. Borovykh L. Problemy praktiki primeneniya ugolovnogo zakonodatel'stva RF ob otvetstvennosti za vzyatochnichestvo, kommercheskii podkup i inye korruptsionnye prestupleniya// Ugolovnoe pravo. 2013. № 5. S. 39-40

7. Plokhov S.V. Protivodeistvie korruptsii v sotsial'noi sfere (na primere zdravookhraneniya i obrazovaniya Volgogradskoi i Saratovskoi oblastei). Diss... kand. yurid. nauk. - Saratov. - 2013. s. 89

8. Moiseenko V.P. Lishenie spetsial'nogo, voinskogo ili pochetnogo zvaniya, klassnogo china i gosudarstvennykh nagrad kak vid nakazaniya v rossiiskom ugolovnom prave :Ugolovnyi i ugolovno-ispolnitel'nyi aspekty. Diss...kand. yurid. nauk. - 2000. - Rostov-na-Donu. - s. 165

9. Durnev A.E. Kriminologicheskie i ugolovno-pravovye mery bor'by s korystnymi prestupleniyami protiv sobstvennosti. Diss...kand. yurid. nauk. M., 2006. 162 s.

10. Kozlova N. Bastrykin prosit vernut' radikal'nye mery protiv korruptsii / /Rossiiskaya gazeta ot 24 noyabrya 2014.

11. Bukalerova L.A., Fortuna K.A. K voprosu o nakazaniyakh za korruptsionnye sluzhebnye podlogi // Administrativnoe i munitsipal'noe pravo. - 2012. - 6. - C. $17-25$.

12. Kurakin A.V., Kostennikov M.V. Administrativno-pravovoe protivodeistvie korruptsii v sisteme gosudarstvennoi sluzhby i v deyatel'nosti sotrudnikov politsii Rossiiskoi Federatsii i zarubezhnykh gosudarstv // Politseiskaya i sledstvennaya deyatel'nost'. - 2013. - 1. - C. 65 - 83. DOI: 10.7256/2409-7810.2013.1.735. URL: http://www.e-notabene.ru/pm/article_735.html

13. Kostennikov M.V., Kurakin A.V. Administrativno-pravovoe protivodeistvie korruptsii v sisteme gosudarstvennoi sluzhby i v deyatel'nosti sotrudnikov politsii Rossiiskoi Federatsii i zarubezhnykh gosudarstv. // Politseiskaya deyatel'nost'. - 2011. 1. - C. $10-16$.

14. Bukalerova L.A., Fortuna K.A. K voprosu o nakazaniyakh za korruptsionnye sluzhebnye podlogi // Administrativnoe i munitsipal'noe pravo. - 2012. - 6. - C. $17-25$.

15. M.V. Kostennikov, A.V. Kurakin, I.N. Koshelev Administrativno-pravovoe regulirovanie obespecheniya sobstvennoi bezopasnosti i protivodeistviya korruptsii v organakh vnutrennikh del (ch. 2) // Administrativnoe i munitsipal'noe pravo. - 2011. $-2 .-$ C. $38-45$.

16. Kurakin A.V., Kostennikov M.V. Administrativno-pravovoe protivodeistvie korruptsii v sisteme gosudarstvennoi sluzhby i v deyatel'nosti sotrudnikov politsii Rossiiskoi Federatsii i zarubezhnykh gosudarstv // Politseiskaya i sledstvennaya deyatel'nost'. - 2013. - 1. - C. 65 - 83. DOI: 10.7256/2409-7810.2013.1.735. URL: http://www.e-notabene.ru/pm/article_735.html

17. Kostennikov M.V., Kurakin A.V. Administrativno-pravovoe protivodeistvie korruptsii v sisteme gosudarstvennoi sluzhby i v deyatel'nosti sotrudnikov politsii Rossiiskoi Federatsii i zarubezhnykh gosudarstv. // Politseiskaya deyatel'nost'. - 2011. 1. - C. $10-16$. 